\title{
Human Capital, Innovation Awareness, Social Responsibility, and Human Resource Success
}

\author{
Rapheephan Phonginwong, Nuttawut Chookhun, Chairung Chaikambang, Napaporn Shupkulmongkol, \\ and Sasiphimmat Hongsombud
}

\begin{abstract}
This research aimed to study the human capital, innovation awareness, social responsibility and human resource success. The samples included 243 entrepreneurs selected from small and medium enterprises in Buriram province, Thailand. The research consisted of correlation analysis and regression analysis. The result showed that 1) The human capital and innovation awareness were positive to human resource success, and 2) The social responsibility had not positive effects on the success of human resource management in the SMES (model4). The result of this research provided useful suggestions for more effective management of human resource within the context of small and medium enterprises in Buriram Province, Thailand.
\end{abstract}

Index Terms-Human capital, innovation awareness, social responsibility, human resource success.

\section{INTRODUCTION}

At present, there are a number of small sized and medium-sized enterprises in Thailand that have access to the international businesses because Thailand is one of the ASEAN members and the Thai government subsidized the multinational businesses to invest in Thailand. Therefore, it is important that Thai business is required to be one of the international businesses. In addition, the Thai government has the policy to develop Thailand into a 4.0 Model or Thailand 4.0 Model aiming to be a country with value based economy. The country with value based economy is the country that produces the innovative products and uses the technology and creativity for production. Therefore, the Thai government policy is an important variable to encourage the Thai businesses for international competitions.

Previous research studies showed that Thai enterprises used the human resource to develop their businesses. There were many businesses supporting their employees to train and study at a higher level. Moreover, they motivated the employees to show their competency in applying the knowledge and skills to do their jobs [1]. Thus, the outcome would be the business performance. Likewise, the businesses could survive because the businesses focused on human resource development (HRD) in the process of organizational development and personal training in order to improve performance. Human resource development is mainly based on three foundation theories; namely, the economic theory, system theory and psychological theory. Human resource development is defined as a process for employees to learn,

Manuscript received May 30, 2018; revised July 27, 2018.

Rapheephan Phonginwong is with Buriram Rajabhat University, Thailand (e-mail: drrapheephan@gmail.com). train and finally, have the expertise. The business performance will depend on the employees who have the skill and the expertise [2].

On the other hand, some of the scholars in human resource management pointed that businesses must have the performance because the business account for the three components: perspective, outcome and transformation. The first one is that the businesses focus on the human capital. The second is the outcome of the human resource. Finally, the businesses enhance the transformation and use innovations to support the operation [3]. However, some other scholars of management argued that if there was any social responsibility, the reputation of the organization could become more increasingly deemed. For example, the businesses provide scholarships to children in the local community and pay for compensation to their employees. Accordingly, this research was an attempt to study how the human capital could be the most important element owing to the fact that this recourse is rare. This capital to some extent can influence the organization. The innovation is the technology information to support the process of work. The social responsibility will positively affect the businesses performance.

\section{THEORY FRAMEWORK}

The current study focused on the Resource-based View: RBV which explains the conceptual framework. It is the fundamental theory of corporate resources (Resource Base View of the Firm) for any organization with the resources and value that is added to the income, which is rare and unlike imitation; it may not use any substitute [4]. If the organization applies this theory to the available resources, it will result in having advantages for the organization's competitive opportunities. This is because the organization has the resources to respond to the changes in the external environment [5].While Barney Bay presents a concept referring to resource assets (assets), capacity (capabilities), the organization of work (organization process) identity of the business or property (firm attributes), information technology (information) knowledge (knowledge) in which these resources are accessible and controllable

In this research, an organization consisted of the human resource and more competitive advantage than the same industry and organization. It focused on the innovation because the innovation was instrumental to the operation. Likewise, the social responsibility was the variable to achieve the businesses reputation. The RBV supported the conceptual ground in this study consisting of four variables as displayed in Fig. 1. 


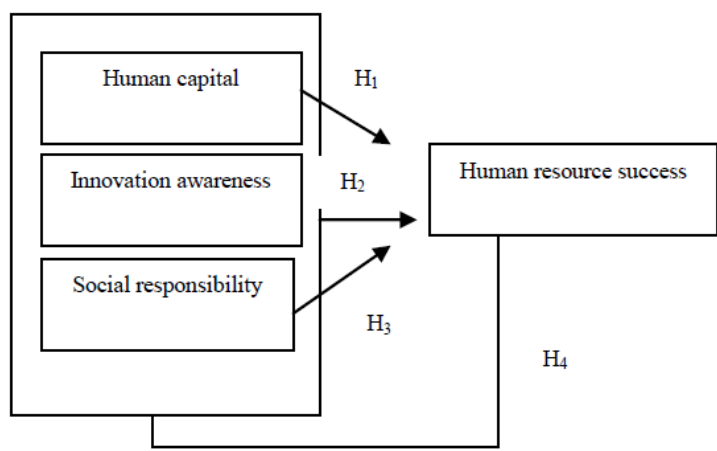

Fig. 1. Magnetization as a function of applied field.

\section{LITERATURE REVIEW AND HYPOTHETICAL DEVELOPMENT}

Human capital referred to the level of the organizational investment in the budget for the employees and the money allocated for employee education and training. The human capital involves an economic perspective with the organization having the capital to train employees [6] Therefore, the organization must have the cost of investment for employees. Likewise, the organization will have to encourage the employees to be enthusiastic and hardworking. The organization has to motivate the employees to show their high level of competency, skill and experience. Thus, based on this brief literature review, the human capital is related to the human resource success, and it was hypothesized as follows:

Hypothesis 1: The human capital will be positively related to the human resource success

Innovation awareness refers to the level of the entrepreneurs that use the information technology to encourage the organizational operation. For example, the information technology is used as a tool to communicate with customers. The organization purchases the materials from the supplier. In addition, the organization uses the information technology to perform the appraisal of the employees. The innovation is considered as the first tool to gain competitive advantages in the organization and the innovation is the variable on the way to increase the business accomplishment [7]. Therefore, based on the extant literature, the innovation awareness related to the human resource success, was hypothesized as:

Hypothesis 2: The innovation awareness will be positively related to the human resource success

Social responsibility refers to the level of the firm activities which are responsible to the public and community. The previous research showed that the corporate concerns on the society and the result of all activities had the positive effects on firm performance since firms have high profit. In this study, social responsibility was defined as the degree of the firm that preferred the community and governance. For example, the firm focused on the local employees to work in the firm and the firm had the suitable and fair procedure of paying salary [8]. Hence, these ideas led to posit the following hypotheses.

Hypothesis 3: The social responsibility will be positively related to the human resource success
Human resource success refers to the level of the employees' job satisfaction and organizational commitment. That is to say, the employees are dedicated to work and have the organizational citizenship behavior [9].

Hypothesis 4: The human capital, innovation awareness, social responsibility will be positively related to the human resource success

\section{RESEARCH METHODOLOGY}

\section{A. Sample and Data Collection Procedure}

The population of 544 was from the small and medium enterprises in accordance with the List of Industry of Buriram Thailand in 2016. For this research, the questionnaires and the simple random sampling were employed. The samples were the 243 entrepreneurs of small and medium enterprises in Buriram province. The questionnaires were distributed to offices of the small and medium enterprises and then 243 questionnaires were completed.

\section{B. Variables}

In this study, there were four variables measured by 5-point Likert's scale. The human capital was evaluated by the level of the number of budget which the organization paid for the education and training the employees, the level of competency of employees operated in every activity, and the use of five-item scale for human capital [10].

Innovation awareness was evaluated by the level of the organizational use of the information technology in the process of production and customer services. For example, the organization performed appraisal on the employee's performance, the organization used information technology to support the training. The innovation awareness comprised of five-item scale

Social responsibility was evaluated by the level of the organizational budget set aside to encourage the activities for society or community. The organization focused on the local employees working in the firm. The social responsibility used five-item scale [11].

Human resource success was evaluated by the level of the ratio employees arrived at, their loyalty and their dedication to work, their application of knowledge and previous training to work, their satisfaction with the salary which they received from the organization. The human resource success used five-item scale.

\section{Reliability and Validity}

This study was assessed by the measurement model using confirmatory factor analysis (CFA) and hypothesis testing by using multiple regression analyses by $n=30$. The set of items to CFA to test validity of construct, all factors loading were 0.498 to 0.906 as being greater than 0.40 cut-offs and statistically significant the rule-of-thumb [12] The results were displayed in Table I. The reliability of the measurement was evaluated by Cronbach's alpha coefficients. The value of Cronbach's alpha coefficient for all constructs was higher than the 0.6 cut off value by Hair [13]. However, in this research, it ranged from 0.566 to 0.813 , where the result of the 
Cronbach's alpha coefficient of human capital was under the value (Hair, 2006). The results, therefore, were shown in Table I and each item was evaluated according to their expert opinions as to whether each item was measured for what had been intended to measure (content validity).

To prevent possible response bias problems between respondents and non-respondents, a t-test comparison of the all variables means between early and late respondents was conducted in correspondence with the test for non-response bias by Amrmstrong \& Overton [14]. The results showed there was no significant difference between early and late respondents demonstrates non-response bias between respondents and non-respondents, and the latest respondents represented non-respondents. Thus, non- response bias was unlikely to be problematic in this research.

TABLE I: RESULTS OF MEASURE VALIDIATION $(N=30)$

\begin{tabular}{lcc}
\hline \hline Items & Factor loading & \multicolumn{2}{c}{ Cronbach Alpha } \\
\multicolumn{1}{c}{ Human capital ( HC) } & $.498-.837$ & .566 \\
\hline Innovation awareness (IA) & $0.785-0.906$ & 0.794 \\
Social responsibility (SR) & $0.619-0.846$ & 0.792 \\
Human resource success & $0.681-0.806$ & 0.813 \\
(HS) & & \\
\hline \hline
\end{tabular}

\section{Hypothesis Testing}

This study utilized regression analysis in order to validate the research framework and hypotheses. The independent variables were entered into the equations as a group (stepwise method). The grades calculated from exploratory factor analysis were used. Data in the human capital, innovation awareness, social responsibility and human resource success were made in average. The conceptual models were specified as follows.

$$
\begin{gathered}
\mathrm{HS}=\beta_{01}+\beta_{0}{ }_{2} \mathrm{HC}+\varepsilon_{1} \\
\mathrm{HS}=\beta_{03+} \beta_{04} \mathrm{IA}+\varepsilon_{1} \\
\mathrm{HS}=\beta_{05+} \beta_{06} \mathrm{SR}+\varepsilon_{1} \\
\mathrm{HS}=\beta_{07+} \beta_{08} \mathrm{HC}+\beta_{09} \mathrm{IA}+\beta_{10} \mathrm{SR}+\varepsilon_{1}
\end{gathered}
$$

Before expounding the results of the regression analysis, this study examined the possible multicolinearity problems in studying correlations between the variables including the regression analysis. By means of Pearson's correlation coefficient, we can measure the degree of linear associated with every pair of variables. The descriptive statistics and correlation matrix for all variables were exactly presented. The verified muliticollinearity problems by intercorrelations among independent variables were not higher than the 0.8 cut-offs [15]. The VIFs range of 1.00, was well below the cut-off value of 10 as recommended by Neter, Wasserman \& Kutner [16], meaning the independent variables were not correlated with each other. Therefore, there were no substantial multicollinearity problems encountered in this study as shown in Table II.

TABLE II: DESCRIPTIVE STATISTICS AND CORRELATION MATRIX ( $N=243)$

\begin{tabular}{|c|c|c|c|c|}
\hline \multirow[t]{2}{*}{ Variables } & \multicolumn{4}{|c|}{ Dependent Variables } \\
\hline & Model 1 & Model 2 & Model 3 & Model 4 \\
\hline & Human resource success(HS) & Human resource success(HS) & Human resource success(HS) & Human resource success(HS) \\
\hline $\begin{array}{l}\text { Human capital } \\
\text { ( HC) }\end{array}$ & $\begin{array}{c}0.619 * * * \\
(.051)\end{array}$ & & & $0.108 * * *$ \\
\hline $\begin{array}{l}\text { Innovation } \\
\text { awareness (IA) }\end{array}$ & & $\begin{array}{c}0.675 * * * \\
(.048)\end{array}$ & & $0.927 * * *$ \\
\hline $\begin{array}{l}\text { Social } \\
\text { responsibility (SR) }\end{array}$ & & & $\begin{array}{c}0.657 * * * \\
(.054)\end{array}$ & $-0.067 * * *$ \\
\hline Adjust $\mathrm{R}^{2}$ & 0.380 & 0.453 & 0.429 & 0.979 \\
\hline VIF & 1.940 & 1.638 & 1.834 & 1.653 \\
\hline
\end{tabular}

\begin{tabular}{lccc}
\hline \hline Variables & Human Capital ( HC) & Innovation awareness (IA) & Social responsibility (SR) \\
\hline Mean & 4.046 & 4.340 & 4.096 \\
\hline S.D & 0.534 & 0.670 & 0.633 \\
\hline Human capital ( HC) & 1 & & 0.590 \\
Innovation awareness (IA) & $0.668^{* * *}$ & 1 & 1 \\
Social responsibility (SR) & $0.622^{* * *}$ & $0.609 * * *$ & $0.672^{* * *}$ \\
Human resource success (HS) & $0.627 * * *$ & $0.677 * * *$ & 1 \\
\hline \hline
\end{tabular}

**** $p<.01, * * p<.05, * p<.10$, Beta coefficients with standard error in parenthesis

TABLE III: RESULTS OF OLS REGRESSION ANALYSIS

\section{RESULT}

Table III presented the results of OLS regression of the relationships among human capital, innovation awareness, social responsibility and human resource success which had been previously shown in Model 1, Model 2, Model 3 and Model 4.

Model 1: the human capital was positive on the human resource success $\left(H_{1}: b_{2}=0.619, p<0.00\right)$. According to the work by Mumun, Saufi \& Ismail, it was found that the organization had the high skill employees because they had the job experience. In addition, it was found that the organization motivated the employees to show their competency, skill and high experience, and that the employees had the organizational commitment. Hence, the organization had achieved the human resource success that supported $H_{1}$.

Model 2: the results showed that the innovation awareness positively influenced the human resource success. The 
previous research studies had indicated that the innovation was the first tool used to gain competitive advantages of organization and it was the variable on the way to increase business success. The organization used information technology to serve the customers and support the processing operation in the businesses [7]. In summary, the innovation awareness positively affected the human resource success and supported the results of $\mathrm{H}_{2}\left(\mathrm{H}_{2}: b_{4}=0.675, p<0.00\right)$.

Model 3: the results showed that social responsibility positively influenced the human resource success. The corporate concerns for the society and the degree of firm preferring the community and governance and the result of all activities had positive effects on the firm performance as the firm had high profit [8]. In short, the organization concentrated on the local employees to function dynamically in the businesses. With this aspect, the organization gained social acceptance. Therefore, the results supported $H_{3}\left(H_{3}: b_{6}\right.$ $=0.657, p<0.00)$.

Model 4: the result showed that the human capital, innovation awareness positively influenced the human resource success. It is surprising social responsibility is not significant for human resource success. There were two variables that supported the human resource success, and the previous research suggested that the businesses have the employees with willpower and the high technology, the businesses have the employees with commitment and royalty, and that the information technology support the employee work [2]. Hence, Hypothesis 4 partially supported $H_{4}\left(H_{4}: b_{8}\right.$ $=0.108, p<0.00, b_{9}=0.927, p<0.00, b_{10}=-0.067$, = $p<-0.067)$.

\section{CONCLUSION AND SugGeSTIONS}

This study showed that the results of the human capital, innovation awareness and social responsibility positively influenced human resource success in model 3. The relations between independent variables and the dependent showed high significance since the organization could manage the employees who concentrated on the work and the employees had organizational commitment [1]. Moreover, small and medium enterprises used the information technology to provide customer services, in the process of production and human resource management. Likewise, the RBV theory supported the conceptual framework that the employees had the required experience and they used the skill and knowledge to enhance their job performance. Moreover, the innovation was the variable important to operate businesses [4]. In addition, the businesses focused on the local labor to work in the businesses. Consequently, the businesses will gain the reputation and the social acceptance [8]. It is astonishing that the model 4 has three variables components in the equation. The result show that the social responsibility were not statistically significant. It is possible that small and medium businesses do not have the budget to do social responsibility. In short term, small and medium businesses may use good customer relationships because they will spend less and the businesses produced the green product.

\section{SUGGESTIONS FOR FUTURE RESEARCH}

The current study was conducted within the scope of Buriram province, Thailand. There might be some other variables that had positive influence on the human resource management. Thus, for future research, the researchers ought to enforce the concept of Iceberg Model of McClelland to validate the model [1]. It is also suggested that it should test variables in other contexts. Future research should be conducted in large enterprises and should focus on CSR and Researchers may bring social responsibility to the test again and test another context.

\section{REFERENCES}

[1] M. Spencer et al., Competence at Work, New York, Wiley, 1993, p. 372.

[2] R. Swanson, "Human resource development: Performance is the key," Human Resource Development Quarterly, vol. 6, no. 2, pp. 207-213, 1995.

[3] D. Ulrich, J. Younger, W. Brockbank, and M. Ulrich, "HR from the outside in: Six competencies for the future of human resources," Havard Business Review Press, p. 17, 2012.

[4] J. Barney, "Firm resources and sustained competitive advantage," Journal of Management, vol. 17, no. 1, pp. 99-120, 1991

[5] B. Wanerfelt, "A resource-based vew of the firm," Strategic Management Journal, vol. 5, no. 2, pp. 171-180, 1984.

[6] A. Mamum and R. Saufi, Human Capital, Credit, and Startup Motives: A Study Among, 2016.

[7] H. T. Keh, T. T. M Nguyer, and H. P. Ng, "The effects of entrepreneurial orientation and marketing information on the performance of SMEs," Journal of Business Venturing, vol. 22, pp. 592-611, 2007.

[8] D. Windsor, "Corporate social responsibility: Three key approaches," Journal of Management Studies, vol. 43, pp. 93-114, 2006

[9] C. M. Jardon, Human Capital as Source of Innovativeness in Subsistence Small, 2016.

[10] R. Phong-Inwong and P. Ussahawanitchakit, "Creativity, marketing innovation and marketing success: evidence from home decoration export businesses in Thailand," International Journal of Business Research, vol. 11, no. 4, pp. 89-103, 2011.

[11] S. Prasertsang and P. Ussahawanitchakit, "Corporate social responsibility strategy and, marketing performance and marketing sustainability: An empirical investigation of ISO 14000 businesses in Thailand," International Journal of Business Strategy, vol. 11, no. 3, pp. 58-78, 2011

[12] J. C. Nunnally and I. H. Bernstein, Psychometric Theory, New York, NY: McGraw-Hill, 1994

[13] J. F. Hair et al., Multivariate Data Analysis, $6^{\text {th }}$ ed. New Jersey: Pearson Prentice Hall International, Inc., 2006.

[14] J. S. Armstrong and T. S. Overton, "Estimating Non-response bias in mail surveys," Journal of Marketing Research, vol. 14, pp. 396-402, 1977.

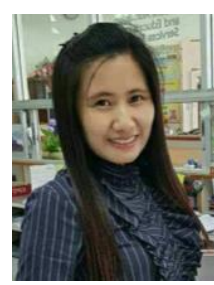

Rapheephan Phonginwong was born in Thailand. She is a lecturer in the human resource management program, Management Faculty, Buriram Rajhaphat University, Thailand. She graduated with a PhD from Mahasarakham University, Thailand. 